\title{
Conduct protocol in emergency: Acute adrenal insufficiency
}

\author{
Adil Bachir Fares ${ }^{1 *}$, Rômulo Augusto dos Santos ${ }^{2}$
}

${ }^{1}$ Medical Student, $6^{\text {th }}$ year, Faculdade de Medicina de São José do Rio Preto (Famerp), São José do Rio Preto, SP, Brazil

${ }^{2}$ Degree in Endocrinology and Metabology from Sociedade Brasileira de Endocrinologia e Metabologia (SBEM). Assistant Physician at the Internal Medicine Service of Hospital de Base. Researcher at Centro Integrado de Pesquisa (CIP). Hospital de Base, São José do Rio Preto. Endocrinology Coordinator of the Specialties Outpatient Clinic (AME), São José do Rio Preto, SP, Brazi

Study conducted at Faculdade de Medicina de São José do Rio Preto (Famerp), São José do Rio Preto, SP, Brazil

Article received: 9/3/2015 Accepted for publication: 9/28/2015

*Correspondence: Address: Av. Deputado Emílio Carlos, 586 São Paulo, SP - Brazil Postal code: 02721-100 adilbf@hotmail.com

\section{SUMMARY}

Introduction: Acute adrenal insufficiency or addisonian crisis is a rare comorbidity in emergency; however, if not properly diagnosed and treated, it may progress unfavorably.

Objective: To alert all health professionals about the diagnosis and correct treatment of this complication.

Method: We performed an extensive search of the medical literature using specific search tools, retrieving 20 articles on the topic.

Results: Addisonian crisis is a difficult diagnosis due to the unspecificity of its signs and symptoms. Nevertheless, it can be suspected in patients who enter the emergency room with complaints of abdominal pain, hypotension unresponsive to volume or vasopressor agents, clouding, and torpor. This situation may be associated with symptoms suggestive of chronic adrenal insufficiency such as hyperpigmentation, salt craving, and association with autoimmune diseases such as vitiligo and Hashimoto's thyroiditis. Hemodynamically stable patients may undergo more accurate diagnostic methods to confirm or rule out addisonian crisis. Delay to perform diagnostic tests should be avoided, in any circumstances, and unstable patients should be immediately medicated with intravenous glucocorticoid, even before confirmatory tests.

Conclusion: Acute adrenal insufficiency is a severe disease that is difficult to diagnose. It should be part of the differential diagnosis in cases of hypotensive patient who is unresponsive to vasoactive agents. Therefore, whenever this complication is considered, health professionals should aim specifically at this pathology.

Keywords: acute adrenal insufficiency, Addison's disease, addisonian crisis, adrenal crisis.

\section{INTRODUCTION}

The adrenal are glands divided in two histological areas: cortex and medulla. The adrenal cortex is composed of three layers: zona fasciculata, zona glomerulosa and zona reticularis, producing mainly cortisol, aldosterone, and estrogens and androgens, respectively. ${ }^{1}$

Aldosterone, a potent mineralocorticoid, is very important for the control of blood pressure and volume, by increasing sodium reabsorption and potassium secretion in the distal tubules of the kidneys. Cortisol is a glucocorticoid of great relevance in body stress, acting on the increase of blood glucose, on plasma concentrations of proteins and lipids, and as an anti-inflammatory agent. At high concentrations, it has relevant lymphopenic and eosinopenic effects. Among the many adrenal androgens, the main one is dehydroepiandrosterone (DHEA), which has weaker effect in humans, contributing to the development of secondary sexual characteristics. ${ }^{1,2,6}$

Given the importance of adrenal hormones, severity of adrenal insufficiency (AI) or adrenocortical becomes clearer. It is clinically manifested in two forms: acute and chronic. In addition, AI can be further divided into: primary AI, known as Addison's disease, a result of destruction of $90 \%$ or more of the adrenocortical gland or conditions that involve the decreased production of adrenal steroids, resulting in subnormal synthesis of aldosterone, cortisol, and androgens; and secondary and tertiary AI, which have their pathophysiology linked to deficient secretion of cor- 
ticotropin (ACTH) and corticotropin releasing hormone $(\mathrm{CRH})$, respectively. ${ }^{2,17} \mathrm{ACTH}$ is a hormone secreted by corticotropic cells of pars distalis in the hypophysis. It is upregulated by $\mathrm{CRH}$, which is produced in the paraventricular nucleus of the hypothalamus (Figure 1).

\section{Method}

Between the months of April and June 2015, we performed extensive literature search and review to find the most current articles on acute adrenal insufficiency (acute AI). Initially, we selected synonyms for acute AI, including: addisonian crisis and adrenal crisis, which were used as keywords in our search for articles and dissertations from databases such as Uptodate, Pubmed, and Scielo.

This study aimed to find and review the most recent articles in English or Portuguese on the subject studied, but without being oblivious to very important articles that, though older, bring useful and still prevalent information on the subject. Therefore, all relevant articles that contributed with solid knowledge regarding conduct and the diagnosis of possible acute $\mathrm{AI}$ in humans (some articles refer to this pathology in animals) were included, while those that did not follow this logic were excluded from the analysis. 175 articles were found initially, of which we selected 20. For better anatomical and pathophysiological understanding of the subject, important books in the academic circles were also used as a source of knowledge.

\section{ACUTE ADRENAL INSUFFICIENCY (ADDISONIAN CRISIS OR ADRENAL CRISIS)}

The addisonian crisis is a relatively uncommon endocrine emergency that translates to serious risk of death if not diagnosed and treated in time. It is usually seen in patients with chronic AI exposed to acute stress such as trauma, surgery, infections, and dehydration. Other causes are displayed in Chart 1. $3,7,8,11,16-18$

The physician should always be alert to any changes in the vital signs of a patient with known chronic AI. Being aware and knowing how to correlate certain signs and

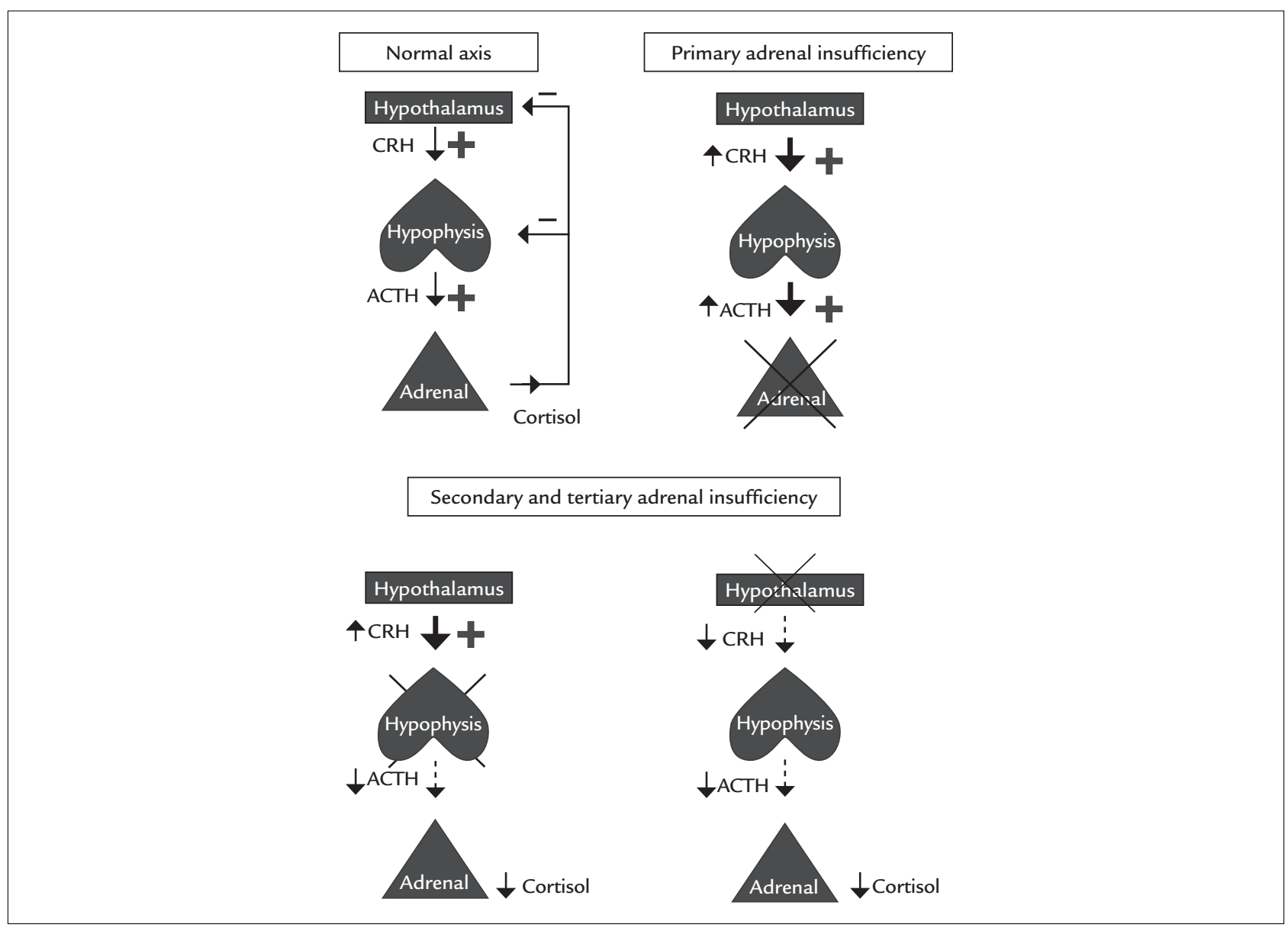

FIGURE 1 Schematic comparison of the adrenal physiology and pathophysiology of the adrenal insufficiency. CRH: corticotropin-releasing hormone; $\mathrm{ACTH}$ : adrenocorticotropic hormone. 
CHART 1 Triggering factors of adrenal insufficiency.

\begin{tabular}{l} 
Infections \\
\hline Surgeries \\
\hline Dehydration \\
\hline Lack of early diagnosis \\
\hline Improper adjustment of glucocorticoid dose, or abrupt withdrawal \\
in chronic users \\
\hline Isolated and hasty replacement of thyroid hormones in patients with \\
hypothyroidism and hypocortisolism \\
\hline Use of drugs that inhibit adrenal steroidogenesis (ketoconazole, \\
aminoglutethimide, metyrapone, mitotane, etc.) \\
\hline Bilateral adrenal hemorrhage \\
Meningococcemia (Waterhouse-Friderichsen syndrome) \\
Use of anticoagulants \\
Trauma or abdominal surgeries \\
Sepsis due to other bacteria ( $P$. aeruginosa) \\
Coagulopathies \\
Leukemia \\
Metastasis \\
Sequel from bilateral venography \\
Primary antiphospholipid syndrome \\
\hline Acute myocardial infarction \\
\hline Hypoglycemia \\
\end{tabular}

symptoms that suggest acute $\mathrm{AI}$ is also necessary, as over $25 \%$ of patients with Addison's disease are diagnosed at the time of an adrenal crisis, probably triggered by a stressful event (surgery, infection or trauma). ${ }^{4,16,18}$

Adrenal crisis should be included in the differential diagnosis when a patient enters the emergency room with hypotension that does not respond to the administration of volume or vasopressors, worsening on standing position, sometimes leading to shock, associated with nonspecific symptoms such as anorexia, nausea, vomiting, pain unexplained abdominal bloating, constipation, fever secondary to an infectious process, apathy, confusion, and drowsiness, which may progress to coma. ${ }^{3,9,13,14,17,18,20}$

A suggestive sign of past Addison's disease, which can help make the diagnosis, is hyperpigmentation of mucous membranes and skin by melanin due to the excessive production of alpha-MSH (melanocortin stimulating hormone) derived from the same precursor protein of ACTH called POMC (pro-opiomelanocortin). This change in skin mainly affects areas exposed to the sun or pressure areas like fingers, knees, and ankles, in addition to the lips and nipples. Other signs and symptoms that should draw attention to a previous primary AI are salt craving and vitiligo. ${ }^{4,5,20}$
The clinical picture that allows us to suspect a secondary AI is: pallor, but with no changes in red blood cells that could suggest anemia, and symptoms of hypogonadism (loss of axillary and pubic hair, loss of libido, and amenorrhea in women). In secondary AI, usually there is no aldosterone deficiency because the renin-angiotensin system is intact; however, it may be associated with hyponatremia due to reduced water clearance resulting from hypocortisolism. ${ }^{3,4}$ The most common manifestations of acute AI can be seen in Chart 2 .

\section{CHART 2 Clinical manifestations of acute} adrenal insufficiency.

\begin{tabular}{ll} 
High fever & Abdominal pain \\
\hline Tachycardia or bradycardia & Apathy and tiredness \\
\hline Dehydration & Nausea and vomiting \\
\hline Hypotension and shock & Anorexia \\
\hline Cyanosis or paleness & Malaise \\
\hline Petechiae and ecchymosis (Waterhouse- & Constipation \\
-Friderichsen syndrome) & \\
\hline Faintness, numbness & Myalgia and arthralgia \\
\hline Coma & Syncope \\
\hline
\end{tabular}

\section{LABORATORY TESTS}

Some immediate laboratory changes may be observed with plain doses of $\mathrm{Na}^{+1}, \mathrm{Ca}^{+2}, \mathrm{~K}^{+}$, blood glucose, and urea. Sodium tends to fall (hyponatremia) and potassium tends to rise (hypercalcemia) due to decreased aldosterone. There is a drop in blood glucose due to serum decrease of an important hormone counter-regulator of insulin, cortisol. Decreased levels of this hormone also lead to an increase in lymphocytes and eosinophils, as a result of decreased immune-modulatory action of hydrocortisone. In some cases, mild hypercalcemia (rarely) and uremia (55\% of cases) are observed. ${ }^{3,9,12,18}$

Diagnosis can generally be achieved by measuring baseline levels of cortisol between 8:00 and 9:00 AM. The diagnosis of AI is confirmed if the value is less than $5 \mu \mathrm{g} / \mathrm{mL}$ (some authors consider $<3 \mu \mathrm{g} / \mathrm{mL}$ ). Values greater than $18 \mu \mathrm{g} / \mathrm{mL}$ should prompt physicians to seek alternative diagnoses. ${ }^{18}$

In case of diagnostic uncertainty, cortrosyn test can be used. It consists of the administration of a semi-synthetic ACTH (cosyntropin) aiming to stimulate the cortex of the adrenal glands. Then, a $250 \mu \mathrm{g}$ dose is intramuscular (IM) or intravenous (IV) administered and cortisol is measured 30 minutes after infusion (some authors recommend dosing at 0,30 and 60 minutes). Values equal to or greater than $18 \mu \mathrm{g} / \mathrm{dL}$ indicate a normal response 
excluding primary and secondary AI with adrenal atrophy; however, this does not rule out a mild or recent deficiency of ACTH. A cortisol peak $<18 \mu \mathrm{g} / \mathrm{dL}$ confirms the diagnosis of AI, without, however, differing from primary or secondary AI, which does not change in therapeutic management table adrenal crisis. ${ }^{14}$

The normal value of plasma ACTH is typically 10 to $60 \mathrm{pg} / \mathrm{mL}$ in most of the laboratory methods used. At levels greater than $100 \mathrm{pg} / \mathrm{mL}$, diagnosis of Addison's syndrome is invariably established. In secondary AI, however, values less than $10 \mathrm{pg} / \mathrm{mL}$ or values in the lower limits of normality are observable. , $^{3,14,20}$

Although the cortrosyn test is the most suitable for diagnosis, it should not be chosen for unstable patients, in which case the serum level of cortisol should be dosed when the central venous access is obtained. Values $<5 \mu \mathrm{g} / \mathrm{dL}$ and $>34 \mu \mathrm{g} / \mathrm{dL}$, respectively, confirm and rule out the diagnosis of hypercortisolism. ${ }^{13}$

It is also important to point out that electrocardiogram (ECG) changes are commonly observed. These changes are due to hyperkalemia, which occurs with peaked T wave ("tent-shaped"), $\mathrm{P}$ wave flattening, and widening of the QRS complex, and in some cases, atrial asystole, intraventricular block, and ventricular asystole.

\section{Treatment}

As discussed so far, an adrenal crisis consists of a set of specific signs and symptoms that require rapid action if there is clinical and hemodynamic instability. In this case, the consensus in all services is to treat hypotension or shock, and to correct hypoglycemia and electrolyte imbalance, even before adopting measures to reach a specific diagnosis.

Therefore, adrenal crisis should always be in our diagnostic spectrum when we encounter a patient who comes to the emergency room dehydrated, hypotensive, pale, presenting abdominal pain, hypoglycemia, weakness, anorexia, and hyperpigmentation.

After raising the hypothesis of acute AI, we must first evaluate the hemodynamic status of the patient. In patients who are hypotensive or inadequately perfused, it is possible to take blood samples, after obtaining venous access, and dose plasma levels of ACTH, cortisol, and electrolytes, immediately correcting fluid imbalance. Infusion of saline crystalloid solution at $0.9 \%$ should be carried out intravenously, 20 to $30 \mathrm{~mL} / \mathrm{kg}$ in 1 hour, observing possible comorbidities related to volume overload. After correction of hypovolemia, intravenous hydration should be maintained at a slow speed rate of 125 to $250 \mathrm{~mL} / \mathrm{h}$ for 24 to 48 hours. Importantly, administration of hypotonic solutions is contraindicated, as this would lead to dilution of natremia. ${ }^{5,17,18}$
In this patient, glucocorticoid administration should be started:

- Hydrocortisone, $100 \mathrm{mg}$, IV, every 6 to 8 hours during the first 24 hours (in unstable patients, the dose of $100 \mathrm{mg}$ every 6 to 8 hours can be maintained until their condition stabilizes). On the second day, when the patient is already stabilized, $50 \mathrm{mg}$ are administered every $6 \mathrm{~h}$. After this, the dose can be gradually reduced on the $4^{\text {th }}$ or $5^{\text {th }}$ day until reaching a maintenance dose. ${ }^{5,14,17-20}[$ In primary AI, fludrocortisone can be administered (0.05-0.2 mg at 8:00 AM, orally)].,

Maintenance treatment in this case is based on the treatment of chronic AI:

1. In Brazil, the drug of choice is prednisone at a dose of 5 to $10 \mathrm{mg}$ in the morning.

2. Fludrocortisone, 0.05 to $0.2 \mathrm{mg}$ in the morning. If the dose is administered in excess, the patient may present with hypertension and hypokalemia.

3. Dehydroepiandrosterone (DHEA) 25 to $50 \mathrm{mg} /$ day, orally (especially for women). ${ }^{3,19,20}$

4. Clinical follow-up: maintaining blood pressure, body weight, electrolytes, and regression of symptoms.

5. Advise the patient to carry an ID card or bracelet.

6. Increase 2 to 3 fold glucocorticoid dose in periods of stress (infections, sepsis, surgery). The injectable form should be offered in times of crisis. ${ }^{18,19}$

During the replacement of glucocorticoids in an outpatient setting, other forms can be chosen, taking into account the equivalent dosages cited in Chart 3.

Nevertheless, dexamethasone or betamethasone should be avoided because of the increased likelihood of developing exogenous Cushing's syndrome and especially due to their low mineralocorticoid effect. ${ }^{2}$

\begin{tabular}{lll} 
CHART 3 Pharmacokinetics of glucocorticoids. \\
Drug & $\begin{array}{l}\text { Equivalent } \\
\text { dose } \mathbf{( m g )}\end{array}$ & $\begin{array}{l}\text { Plasmatic half-life } \\
\text { (hours) }\end{array}$ \\
\hline Hydrocortisone & 20 & $8-12$ \\
\hline Cortisone & 25 & $8-12$ \\
\hline Prednisone & 5 & $12-36$ \\
\hline Prednisolone & 4 & $12-36$ \\
\hline Methylprednisolone & 4 & $12-36$ \\
\hline Triamcinolone & 4 & $12-36$ \\
\hline Betamethasone & 0.6 & $36-72$ \\
\hline Dexamethasone & 0.75 & $36-72$ \\
\hline
\end{tabular}

Hahner $\mathrm{S}^{10}$ and Ten $\mathrm{S}^{11}$, modified. 


\section{Prevention of a new addisonian Crisis}

After the end of an acute adrenal crisis, the patient must necessarily take some simple steps to prevent a new acute episode:

1. The patient should be informed of the existence of $\mathrm{AI}$ (if it has been discovered only during the crisis), the need to maintain a permanent treatment throughout life, and the severity of adrenal crises.

2. As mentioned, the patient must carry some form of identification of their underlying condition..$^{15,17}$

3. The maintenance dose used in cases of mild stress (infections) should be doubled or tripled in periods of more intense stress (surgeries), and may return to the prior dose after 24 to 48 hours. ${ }^{17}$

4. Follow-up required with a medical specialist.

5. If possible, the patient should take with them a kit with parenteral hydrocortisone for self-administration. ${ }^{15,17,19}$

\section{Conclusion}

As noted in our review, although rare, acute $\mathrm{AI}$ is a serious complication and requires rapid and specific therapeutic action, which will be critical to the patient's prognosis.

Therefore, it is essential that all health professionals are able to recognize the nonspecific symptoms that include orthostatic hypotension unresponsive to volume, anorexia, muscle weakness, paleness, nausea, and vomiting, and at least suspect a possible addisonian crisis.

There are some classical signs and many signs suggestive of AI that may be useful for diagnosis, such as hyperpigmentation or salt craving.

In case of clinical suspicion, it is very important that glucocorticoids (hydrocortisone additional intrinsic mineralocorticoid effect) are promptly administrated, together with fluid replacement to the patient, leaving the final diagnosis to be established when the patient's condition is stable.

So to make it easier to understand and increase the effectiveness in routine emergency services, we have created an algorithm displayed in Figure 2.

\section{Resumo}

Protocolo de condutas em emergência: insuficiência adrenal aguda

Introdução: a insuficiência adrenal aguda ou crise addisoniana é uma comorbidade rara na emergência; porém, se não diagnosticada e tratada de forma correta, pode evoluir de maneira desfavorável.

Objetivo: alertar a todos os profissionais da saúde sobre o diagnóstico e tratamento corretos dessa complicação.

Método: foi realizada uma ampla pesquisa na literatura médica, por meio de ferramentas específicas, sendo selecionados 20 artigos sobre o tema.

Resultados: a crise addisoniana é de difícil diagnóstico pela inespecificidade de seus sinais e sintomas. No entanto, pode ser suspeitada em pacientes que chegam à emergência com queixa de dor abdominal, hipotensão não responsiva a volume ou a agentes vasopressores, obnubilação e torpor. Esse quadro pode vir associado a sintomas sugestivos de insuficiência adrenal crônica, como hiperpigmentação e avidez por sal, bem como a doenças autoimunes, como vitiligo e tireoidite de $\mathrm{Ha}$ shimoto. Pacientes estáveis hemodinamicamente podem passar por métodos diagnósticos mais apurados para se confirmar ou descartar a crise addisoniana. Os exames diagnósticos não podem retardar, em hipótese alguma, o tratamento de pacientes instáveis, que deve ser iniciado imediatamente com glicocorticoide endovenoso, inclusive antes das provas confirmatórias.

Conclusão: a insuficiência adrenal aguda é uma patologia grave e de difícil diagnóstico, que deve fazer parte do diagnóstico diferencial do médico ao atender um paciente hipotenso sem reposta à infusão de drogas vasoativas. Logo, na suspeita dessa complicação, o profissional não deve tardar a agir especificamente nessa patologia.

Palavras-chave: insuficiência adrenal aguda, doença de Addison, crise addisoniana, crise adrenal. 


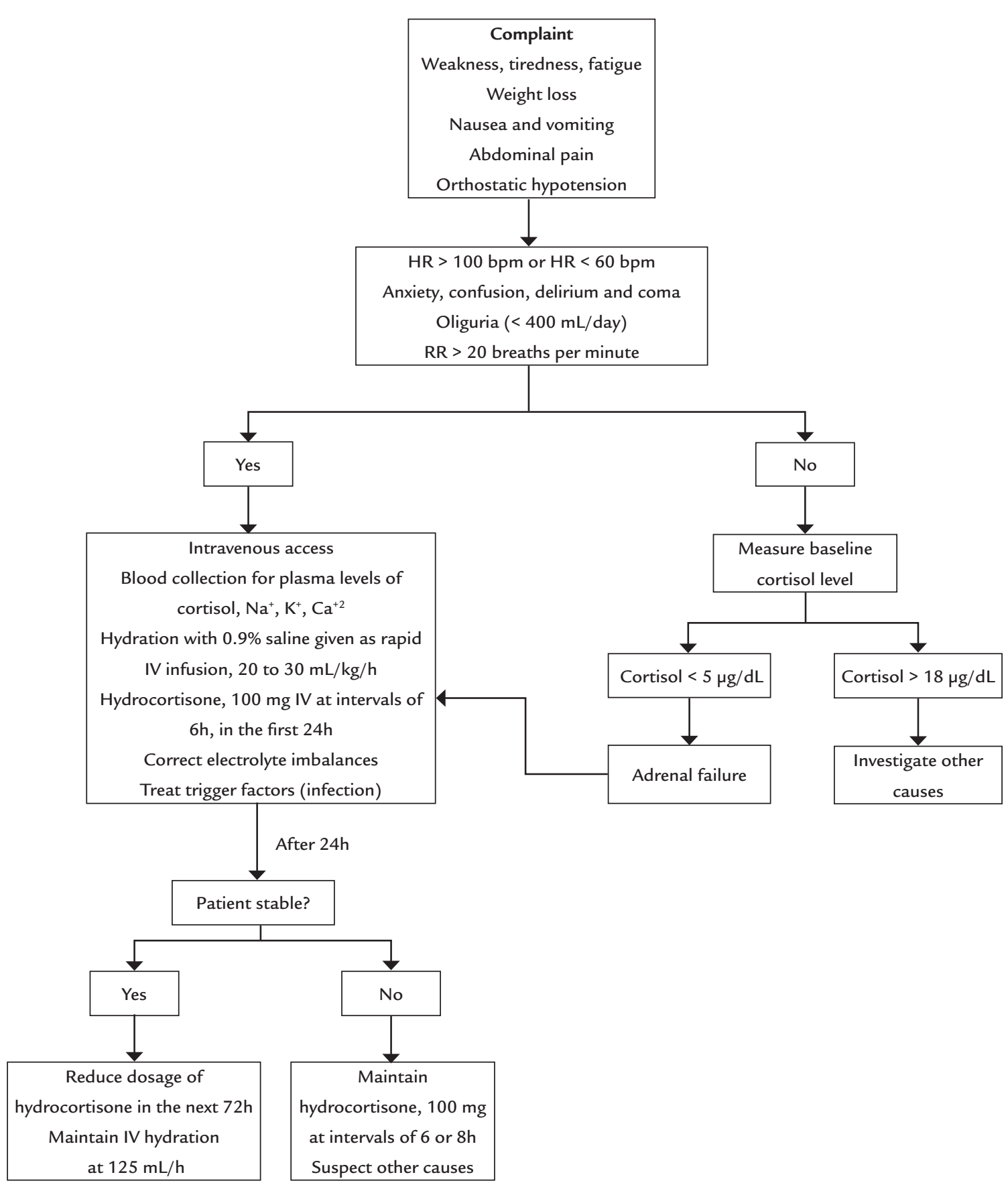

FIGURE 2 Acute adrenal insufficiency algorithm.

HR: heart rate; bpm: beats per minute; RR: respiratory rate; IV: intravenous.

\section{References}

1. Junqueira LCU, Carneiro J. Adrenais. In: Histologia básica. 11. ed. Rio de Janeiro: Guanabara Koogan; 2008. p. 397-403.

2. Guyton AC, Hall JE, editors. Hormônios adrenocorticais. 12. ed. Rio de Janeiro: Elsevier; 2011. p. 944-60.

3. Kater CE, Silva RC, Vilar L. Doenças das adrenais. Insuficiência adrenal Diagnóstico e tratamento. In: Vilar L, editor. Endocrinologia Clínica. 5. ed. Rio de Janeiro: Guanabara Koogan; 2013. p. 399-414.
4. Alves M, Souto SB, Neves C, Carvalho Braga D, Medina JL. Protocolo de diagnóstico e tratamento de insuficiência supra-renal aguda. Rev Port Endocrinol Diabetes Metab. 2008; 1:23-30.

5. Santos RA. Síndrome adrenal aguda. In: Santos RA, Marino EC, Campos RG. Manual de condutas práticas em endocrinologia e metabologia. São José do Rio Preto: THS Editora; 2013. p. 245-6.

6. Carrol.TB, Aron.DC, Findling JW. Glicocorticoides e androgênios suprarrenais In: Gardner DG, Shoback D. Endocrinologia básica e clínica de Greenspan. 9. ed. Rio de Janeiro: Mac Graw-Hill, Artmed; 2013. p. 285-327. 
7. Faiçal S, Silva RC, Moritmisu LK. Insuficiência adrenocortical aguda. In: Frisoli Jr AJ, Lopes AC, Amaral JLG, Blum VF, Ferraro JR. Emergências: manual de diagnóstico e tratamento. 2. ed. São Paulo: Savier; 2004.

8. Betterle C, Morlin L. Autoimmune Addison's disease. Endocr Dev. 2011; 20:161-72.

9. Brandão Neto RA, de Carvalho JF. Autoimmune diagnosis and classification of Addison's disease (autoimmune adrenalitis). Autoimmun Rev. 2014; 13(45):408-11.

10. Hahner S, Allolio B. Therapeutic management of adrenal insufficiency. Best Pract Res Clin Endocrinol Metab. 2009; 23(2):167-79.

11. Ten S, New M, Maclaren N. Clinical review 130: Addison's disease 2001. J Clin Endocrinol Metab. 2001; 86(7):2909-22.

12. Lau SY, Yong TY. Rhabdomyolysis in acute primary adrenal insufficiency complicated by severe hyponatraemia. Intern Med. 2012; 51(17):2371-4.

13. Cooper MS, Stewart PM. Corticosteroid insufficiency in acutely ill patients. N Engl J Med. 2003; 348(8):727-34.
14. Charmandari E, Nicolaides NC, Chrousos GP. Adrenal insufficiency. Lancet. 2014; 383(9935):2152-67.

15. Hahner S, Hemmelmann N, Quinkler M, Beuschlein F, Spinnler C, Allolio B. Timelines in the management of adrenal crisis - targets, limits and reality. Clin Endocrinol (Oxf). 2015; 82(4):497-502.

16. Smans LC, Van der Valk ES, Hermus AR, Zelissen PM. Incidence of adrenal crisis in patients with adrenal insufficiency. Clin Endocrinol (Oxf). 2016; 84(1):17-22.

17. Allolio B. Extensive expertise in endocrinology. Adrenal crisis. Eur J Endocrinol. 2015; 172(3):R115-24

18. Tucci V, Sokari T. The clinical manifestations, diagnosis, and treatment of adrenal emergencies. Emerg Med Clin North Am. 2014; 32(2):465-84.

19. Grossman A, Johannsson G, Quinkler M, Zelissen P. Therapy of endocrine disease: Perspectives on the management of adrenal insufficiency: clinical insights from across Europe. Eur J Endocrinol. 2013; 169(6):R165-75.

20. Michels A, Michels N. Addison disease: early detection and treatment principles. Am Fam Physician. 2014; 89(7):563-8. 